Universidad de Lima

Facultad de Derecho

Carrera de Derecho

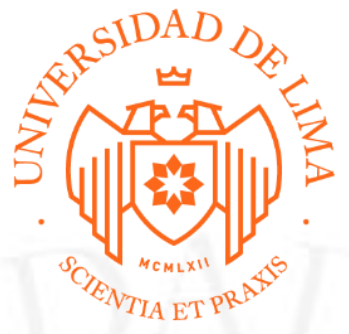

\title{
CIVIL: "PRESCRIPCIÓN ADQUISITIVA DE DOMINIO" E INDECOPI "ELIMINACIÓN DE BARRERAS BUROCRÁTICAS"
}

Trabajo de suficiencia profesional para optar el Título Profesional de Abogado

Diego Paolo Alexander Flores Huarcaya

Código 20081392

Lima - Perú

Enero de 2019 
Materia: Prescripción adquisitiva de dominio

$\mathrm{N}^{\circ}$ de Expediente: 00082-2008-0-1801-JR-CI-01

\section{ÍNDICE GENERAL}

I. Antecedentes relevantes

II. Hechos relevantes

- Primera instancia (Juzgado Especializado en lo Civil del Cono Este)

- Sentencia de primera instancia

- Segunda instancia (Sala Mixta Transitoria de Ate)

- Sentencia de segunda instancia

- Nueva sentencia emitida por el Juzgado

- Sentencia emitida por la Sala

III. Opinión legal sobre las sentencias judiciales

3.1 Resolución $\mathrm{N}^{\circ} 52$ de fecha 24 de mayo de 2010

3.2 Resolución $\mathrm{N}^{\circ} 13$ de fecha 21 de julio de 2010

3.3 Resolución $\mathrm{N}^{\circ} 58$ de fecha 02 de abril de 2012

3.4 Resolución $\mathrm{N}^{\circ} 05$ de fecha 31 de enero de 2013

IV. Opinión del proceso civil en general 
Materia: Eliminación de barreras burocráticas

$\mathrm{N}^{\circ}$ de Expediente: 00124-2014/CEB-2010/CPC

\section{ÍNDICE GENERAL}

I. Antecedentes relevantes

II. Hechos relevantes

- Primera instancia (Comisión de Eliminación de Barreras Burocráticas)

- Resolución Nº423-2014/CEB-INDECOPI emitida por la Comisión

- Segunda Instancia (Sala Especializada en Defensa de la Competencia del INDECOPI)

- Resolución Nº065-2017/SDC-INDECOPI emitida por la Sala

III. Opinión legal sobre las resoluciones administrativas

3.1 Resolución N 0423-2014/CEB-INDECOPI emitida por la Comisión

3.2 Resolución N 0065-2017/SDC-INDECOPI emitida por la Sala

IV. Opinión personal del procedimiento administrativo 